\title{
Article \\ Effect of Moderate-Intensity Endurance Exercise on Inflammatory Cytokines in Leukocytes of Dogs
}

\author{
Hae Sung Lee ${ }^{1}{ }^{(0)}$, Hyun Ju Oh ${ }^{2}{ }^{(0)}$, Kihae $\mathrm{Ra}^{3}$ and Jong-Hee Kim ${ }^{1, *}$ \\ 1 Department of Physical Education, College of Performing Arts and Sport, Hanyang University, \\ 222 Wangsimni-ro, Seongdong-gu, Seoul 04763, Korea; hsleee@hanyang.ac.kr \\ 2 Department of Animal Sciences and Biotechnology, College of Agriculture and Life Science, Chungnam \\ National University, 99 Daehak-ro, Yuseong-gu, Daejeon 34134, Korea; newborn52020@gmail.com \\ 3 Research Institute for Veterinary Science, College of Veterinary Medicine, Seoul National University, \\ Seoul 08826, Korea; ragh1102@snu.ac.kr \\ * Correspondence: carachel07@hanyang.ac.kr; Tel.: +82-2-2220-1325
}

Citation: Lee, H.S.; Oh, H.J.; Ra, K.; Kim, J.-H. Effect of ModerateIntensity Endurance Exercise on Inflammatory Cytokines in Leukocytes of Dogs. Appl. Sci. 2022, 12, 215. https://doi.org/10.3390/ app12010215

Academic Editor: Jesús

García Pallarés

Received: 29 November 2021

Accepted: 22 December 2021

Published: 27 December 2021

Publisher's Note: MDPI stays neutral with regard to jurisdictional claims in published maps and institutional affiliations.

Copyright: (C) 2021 by the authors. Licensee MDPI, Basel, Switzerland. This article is an open access article distributed under the terms and conditions of the Creative Commons Attribution (CC BY) license (https:// creativecommons.org/licenses/by/ $4.0 /)$.

\begin{abstract}
This study aimed to investigate the effect of a treadmill exercise on hematological and serum biochemical parameters and the expression of immune-related cytokine genes in leukocytes. For the experiment, six healthy adult dogs were divided into exercise and control groups. The exercise group performed an endurance exercise three times a week for four weeks. Blood samples were collected before exercise, two weeks after exercise, and post-exercise, and hematological and serum biochemical analysis and cytokine gene analysis were conducted. In the exercise group, white blood cell count (WBC), aspartate aminotransferase, serum alkaline phosphatase, and glucose levels were significantly decreased, but there was no change in the control group. The mRNA expression of TNF- $\alpha$, IFN- $\gamma$, IL-1 $\beta$, and IL-4 was significantly decreased in the exercise group compared to the control group. There was no difference in IL-6, IL-8, and IL-10 mRNA expression between groups. The results in the current study demonstrate that short-term moderate-intensity endurance exercise alters WBC levels and mRNA cytokine expression in leukocytes and may have a meaningful effect on immune health in dogs.
\end{abstract}

Keywords: dog; endurance exercise; cytokine; hematological analysis; serum biochemical analysis

\section{Introduction}

Dogs have long shared environments and lifestyles with humans [1]. In modern society, they are recognized as members of the family beyond the concept of companion animals [2]. Dogs also reveal unique behavior patterns that induce human care and affection [3], resulting in a stronger bond between humans and dogs. Accordingly, many dog owners are striving to improve the welfare of their companions by providing them with a variety of physical activities in daily life, including walks and trotting for obesity prevention, health care, and stress relief [4]. However, it is unclear whether these activities can provide sufficient exercise levels for dogs.

The American College of Sports Medicine (ACSM) provides scientific and detailed exercise guidelines for health benefits that take into account individual characteristics (i.e., gender, age, fitness level, presence or absence of disease, etc.) by comprehensively analyzing numerous studies in the field of human exercise science [5]. The ACSM suggests $\geq 30 \mathrm{~min} /$ day $^{-1}$ moderate and higher exercise intensity with $\geq 50-70 \%$ maximal oxygen uptake $\left(\mathrm{VO}_{2 \max }\right) \geq 3$ day / wk to improve or maintain physical fitness and health in humans [5]. However, there are no established exercise guidelines for dogs, and it is challenging to measure exercise intensity with $\mathrm{VO}_{2 \max }$ due to the problem of using the equipment under experimental control conditions. Maximal heart rate $\left(\mathrm{HR}_{\max }\right)$ is often used to determine exercise intensity in dogs as an alternative measure [6]. Previous studies have demonstrated that the $\mathrm{HR}_{\max }$ of dogs is $220-230$ beats per minute (bpm) by measuring the heart rate during progressive exercise $[6,7]$. According to former exercise data 
based on $\mathrm{HR}_{\max }$ [6-8], dogs who participated in aerobic exercise on a treadmill, reaching $50-70 \% \mathrm{HR}_{\max }$, for four weeks showed positive changes in white blood cell count (WBC) and serum alkaline phosphatase (ALP) levels [8]. In another study, walking $(3.8 \mathrm{~km} / \mathrm{h}$, $10 \mathrm{~min}$ ) followed by running $(7.2 \mathrm{~km} / \mathrm{h}, 20 \mathrm{~min})$ then walking again $(3.8 \mathrm{~km} / \mathrm{h}, 10 \mathrm{~min})$ resulted in a significant change in lactate and glucose levels in the blood serum of dogs [9]. Meanwhile, in a survey of the frequency and duration of walks regarding overweight dogs, $82.5 \%$ of respondents said that their dog walks at least once a day, and $63.2 \%$ said that their dog walks for more than $30 \mathrm{~min}$ per day [10]. Although overweight dogs were often walked, their weight seems to be stagnant. The enforced or voluntary exercise of appropriate frequency, intensity, time and type may be more essential for achieving health and fitness goals for dogs, as suggested in human studies [11,12].

Recent research has focused on the role of exercise in the positive regulation of cytokines [13]. Cytokines are a control system of intercellular signaling molecules produced by various cells for immune and inflammatory reactions with complex mechanisms $[14,15]$. Without stressful stimuli, cytokines are usually regulated at low levels through autocrine or paracrine action [16], but they also serve as physiological protection against tissue damage, injury, and disease [17-19]. In the cytokine response to exercise, moderate levels of exercise induce anti-inflammatory mechanisms, and intense levels of exercise stimulate pro-inflammatory pathways [20]. Interleukin (IL)-6, a pro-inflammatory cytokine, was significantly increased following high-intensity interval exercise $\left(\mathrm{VO}_{2 \max } 90 \%\right)$ compared to low-intensity exercise [21]. In addition, moderate-intensity aerobic exercise over four weeks induced a decrease in tumor necrosis factor-alpha (TNF- $\alpha$ ) [22]. On the other hand, other studies have reported that walking at $\sim 60 \% \mathrm{VO}_{2 \max }$ intensity in healthy female subjects did not affect immune-related parameters [23]. Although numerous studies have been conducted to validate moderate-intensity exercise-induced positive effects on cytokines, the results are inconclusive. As far as we know, no studies have been reported on the topic of canine cytokine regulation by exercise. In dogs, immune regulation by cytokines is valuable in clinical veterinary medicine $[24,25]$, and studies are needed to examine whether exercise intervention can induce positive control of cytokines for dog health.

In our previous study [8], we developed a four-week treadmill exercise program for dog health by applying ACSM's scientific exercise principles (frequency, intensity, time/duration, type, volume, and progression; FITT-VP) [5]. The intensity of this exercise program was around $50 \% \mathrm{HR}_{\max }$, and positive changes in ALP were confirmed [8]. Our previous research focused on developing a safe endurance exercise program that many dog owners could use directly, but the scientific validation of the dog health benefits of exercise is unclear due to the lack of biochemical and molecular analysis. We hypothesized that moderate-intensity endurance exercise in dogs would induce a positive effect on immune function, based on the affirmative results on hematological parameters identified in previous studies. Therefore, the purpose of this study was to investigate the effect of a treadmill exercise program on hematology and serum biochemistry parameters and the expression of immune-related cytokine genes in dogs. Furthermore, verifying the positive effects of short-term endurance exercise on immunity is intended to demonstrate that the exercise program can effectively improve canine health.

\section{Materials and Methods}

\subsection{Animals}

Six healthy male beagles were used in this investigation (Table 1). All dog care met the recommendations described in The Guide for the Care and Use of Laboratory Animals and were consistent with the Institutional Animal Care and Use Committee of Hanyang University (HYU-2020-0073A) and Seoul National University (SNU-180731-2). All methods and protocols were performed in accordance with relevant guidelines and regulations. Before starting the experiments, a veterinarian performed a fundamental hematological analysis and body composition examination. Additionally, all beagle dogs received the same dietary and resting conditions. The dogs were housed in a temperature- 
and humidity-controlled room $\left(22-23^{\circ} \mathrm{C}\right.$ and $\left.50-60 \%\right)$ with a $12: 12 \mathrm{~h}$ light (07:00-19:00) and dark (19:00-07:00) cycle. The dogs were kept in separate cages $(775 \times 960 \times 900 \mathrm{~cm})$ with soft rubber floors cleaned daily. Meals were provided twice a day (09:00, 17:00), and water was provided ad libitum. The dogs were not fed for four hours before the exercise test to prevent exercise-induced gastrointestinal upset, acid reflux, and heartburn.

Table 1. Dog characteristics. Age and weight data are represented as mean $\pm \mathrm{SD}$.

\begin{tabular}{cc}
\hline Parameters (Unit) & Dogs \\
\hline No. of Dogs & 6 \\
Sex & Male \\
Age (month) & $31.8 \pm 15.8$ \\
Weight (kg) & $9.1 \pm 1.3$ \\
\hline
\end{tabular}

Age and weight data are represented as mean \pm SD.

\subsection{Treadmill Adaptation for Dog Safety}

All dogs underwent two weeks of acclimatization periods before the main experiment to familiarize themselves with the researcher, laboratory environment, and exercise regimen. The exercise equipment included a treadmill (EGOJIN XG-V6E, Gyeonggi-do, Korea) and a safety belt attached to the chest of each dog. Each dog's rectal temperature was measured using a digital thermometer before and after exercise. The researcher and veterinarian checked the dogs' behavior and ensured their safety throughout the experiment.

\subsection{Endurance Exercise Program}

As a warm-up, the dogs walked for five minutes at $2-3 \mathrm{~km} / \mathrm{h}$ speed on the treadmill before the endurance exercise. Endurance exercise, a form of physical training with no resting intervals, was provided three times a week for four weeks and included four protocols. All protocols were separated into five sessions (1-5). In protocols 1 to 4, the slope and speed of the treadmill gradually increased as the session progressed. At the start of the following protocol, the slope and speed were reset to their values in the second session of the prior protocol (Table 2).

Table 2. A four-week endurance exercise program consisting of four protocols. The 4 protocols include a gradual increase in slope $(\%)$ and speed $(\mathrm{km} / \mathrm{h})$ as the session proceeds.

\begin{tabular}{|c|c|c|c|c|c|c|}
\hline Protocol & Session & 1 & 2 & 3 & 4 & 5 \\
\hline \multirow{3}{*}{1} & Time (min) & 5 & 5 & 5 & 5 & 5 \\
\hline & Slope (\%) & 0 & 1 & 1 & 2 & 2 \\
\hline & Speed $(\mathrm{km} / \mathrm{h})$ & 3.0 & 3.2 & 3.4 & 3.6 & 3.8 \\
\hline \multirow{3}{*}{2} & Time (min) & 5 & 5 & 5 & 5 & 5 \\
\hline & Slope (\%) & 1 & 2 & 2 & 3 & 3 \\
\hline & Speed $(\mathrm{km} / \mathrm{h})$ & 3.2 & 3.4 & 3.6 & 3.8 & 4.0 \\
\hline \multirow{3}{*}{3} & Time (min) & 5 & 5 & 5 & 5 & 5 \\
\hline & Slope (\%) & 2 & 3 & 3 & 4 & 4 \\
\hline & Speed $(\mathrm{km} / \mathrm{h})$ & 3.4 & 3.6 & 3.8 & 4.0 & 4.2 \\
\hline \multirow{3}{*}{4} & Time (min) & 5 & 5 & 5 & 5 & 5 \\
\hline & Slope (\%) & 3 & 4 & 4 & 5 & 5 \\
\hline & Speed $(\mathrm{km} / \mathrm{h})$ & 3.6 & 3.8 & 4.0 & 4.2 & 4.4 \\
\hline
\end{tabular}

\subsection{Hematology and Serum Biochemistry Parameter Analysis}

A total of $8 \mathrm{~mL}$ blood samples were collected from the jugular vein of the dog and $3 \mathrm{~mL}$ of blood was divided into two EDTA tubes for hematological analysis and mRNA 
extraction. The remaining samples were transferred into a serum separation tube for serum chemistry analysis. After coagulation, the tubes were centrifuged at $3000 \mathrm{rpm}$ for $10 \mathrm{~min}$ to separate serum. Hematology and serum biochemistry analyses were performed within the first six hours after blood collection. EDTA-blood samples for mRNA extraction were stored at $-80^{\circ} \mathrm{C}$ until subsequent use. Hematological parameters were measured from EDTA-blood samples using ADVIA 2120i (NYN Tarrytown, Tarrytown, NY, USA). Biochemistry parameters were measured from serum using the Hitachi 7180 Auto analyzer (Hitachi, Tokyo, Japan) with reagents specifically designed for the instrument. All analysis were carried out according to the schematic design of experimental procedures in Figure 1.

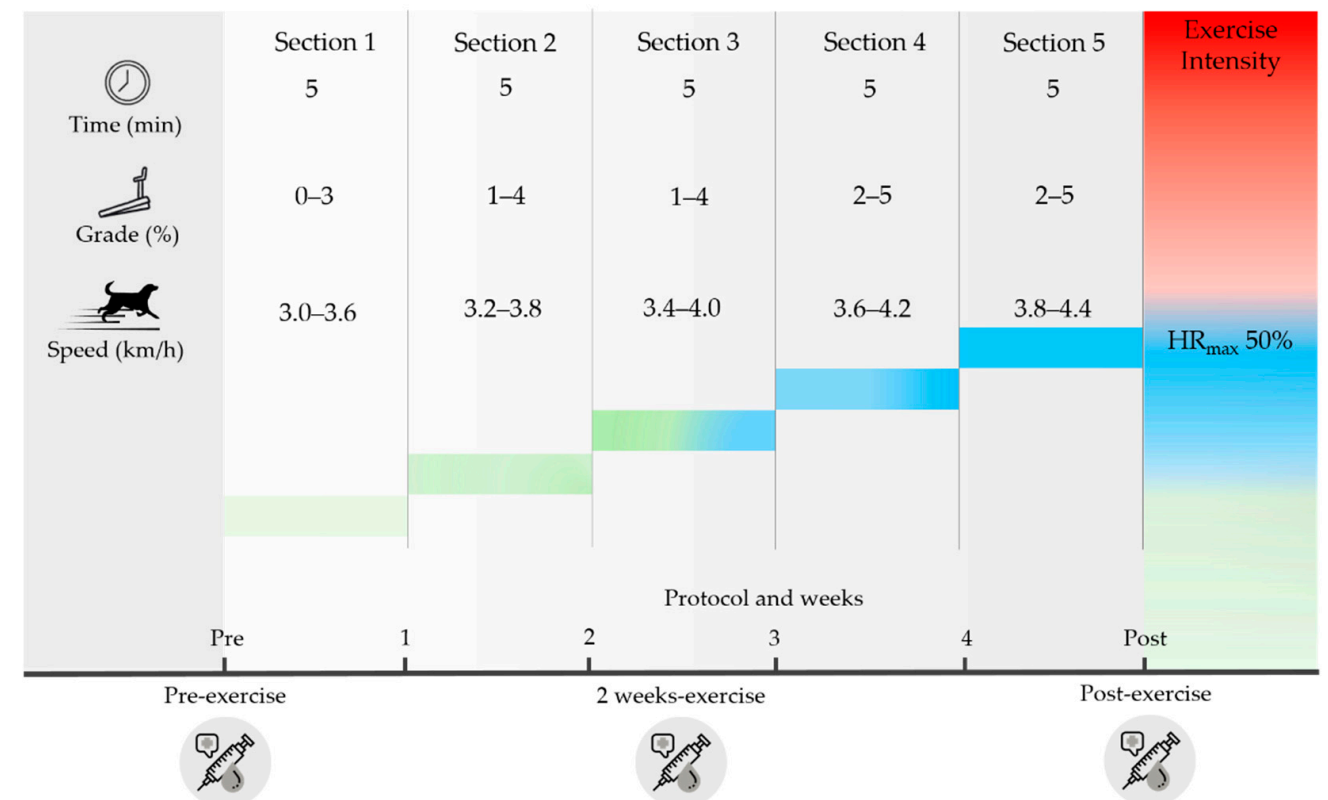

Figure 1. Schematic design of experimental procedures. Dogs underwent endurance exercise comprising five resting stages and four workout stages total of four weeks.

\subsection{Quantitative Reverse Transcription-Polymerase Chain Reaction ( $q R T-P C R$ )}

Regarding total RNA extraction, EDTA-blood samples were collected from dogs before exercise, two weeks after exercise, and post-exercise. Total RNAs were extracted from the leukocytes of all samples following the manufacturer's instructions using the QIAamp RNA Blood Mini Kit (Qiagen, Hilden, Germany). Total RNA extracted was quantified using a NanoDrop 2000 Spectrophotometer (Thermo Fisher Scientific, Wilmington, DE, USA) and stored at $-80^{\circ} \mathrm{C}$ until used for complementary DNA (cDNA) synthesis. cDNA was synthesized using all collected RNA with a Maxime RT premix kit (iNtRON, Gyeonggi, Korea). Quantitative reverse transcription-polymerase chain reaction (qRT-PCR) was performed using the StepOnePlus Real-Time PCR System (Applied Biosystems, Foster City, CA, USA). The final reaction mixture $(20 \mu \mathrm{L})$ included $0.4 \mu \mathrm{L}$ forward primer, $0.4 \mu \mathrm{L}$ reverse primer, $10 \mu \mathrm{L}$ SYBR Green PCR master mix (Applied Biosystems), $8.2 \mu \mathrm{L}$ diethylpyrocarbonatetreated water, and $1 \mu \mathrm{L}$ cDNA under the following conditions: 40 cycles of $95{ }^{\circ} \mathrm{C}$ for $10 \mathrm{~s}$, $60{ }^{\circ} \mathrm{C}$ for $20 \mathrm{~s}$, and $72{ }^{\circ} \mathrm{C}$ for $40 \mathrm{~s}$. The beta-actin gene was used as an internal control to normalize quantification for comparative analyses. Relative gene expressions were calculated using the $2^{-\Delta \Delta \mathrm{Ct}}$ method [26]. The relative formula (R) was assessed using the formula: $\mathrm{R}=2-[\Delta \mathrm{Ct}$ sample $-\Delta \mathrm{Ct}$ control group]; each obtained value was normalized to the beta-actin value, and the average value for each gene expression of both groups at the time point before exercise was set to one [27]. All primer sequences are listed in Table 3.

\subsection{Statistical Analyses}

All data are presented as mean \pm SEM. The statistical analyses were performed using GraphPad Prism 5 (GraphPad Software, Inc., San Diego, CA, USA). Two-way analysis of 
variance (ANOVA) was used to determine the mean difference in each variable, followed by a Bonferroni's post hoc test. Statistical significance was set to $p<0.05$.

Table 3. List of primer sequences used for real-time qPCR.

\begin{tabular}{lll}
\hline Gene & Primer Sequence $\left(\mathbf{5}^{\prime} \rightarrow \mathbf{3}^{\prime}\right)$ & Accession Number \\
\hline \multirow{2}{*}{-actin } & $\begin{array}{l}\text { F: GCGCAAGTACTCTGTGTGGA } \\
\text { R: ACATTTGCTGGAAGGTGGAC }\end{array}$ & NM_001195845.2 \\
\hline IFN- $\gamma$ & $\begin{array}{l}\text { F: CGCAAGGCGATAAATGAACT } \\
\text { R: GACTCCTTTTCCGCTTCCTT }\end{array}$ & NM_001003174.1 \\
\hline TNF- $\alpha$ & $\begin{array}{l}\text { F: CCCCAAGTGACAAGCCAGTA } \\
\text { R: CTCAGCTTCGGGGTTTGTA }\end{array}$ & NM_001003244.4 \\
\hline IL-4 & $\begin{array}{l}\text { F: ACTCACCAGCACCTTTGTCC } \\
\text { R: CTCGCTGTGAGGATGTTCAA }\end{array}$ & NM_001003159.1 \\
\hline IL-1 $\beta$ & $\begin{array}{l}\text { F: TTGTGCACGGGGATGAAAGT } \\
\text { R: TTGATGCCCAAGACCACAGG }\end{array}$ & NM_001037971.1 \\
\hline IL-6 & $\begin{array}{l}\text { F: GCAGGAGATTCCAAGGATGA } \\
\text { R: TTGTTTGCAGAGGTGAGTGG }\end{array}$ & NM_001003301.1 \\
\hline IL-8 & $\begin{array}{l}\text { F: TCAGAACTTCGATGCCAGTG } \\
\text { R: GGGCCACTGTCAATCACTCT }\end{array}$ & AF048717.1 \\
\hline R: CCTGTCGGAGATGATCCAGT & NM_001003077.1 \\
\hline
\end{tabular}

\section{Results}

\subsection{Effect of Exercise on Hematological and Serum Biochemistry Parameters}

Table 4 presents the differences in hematological and serum biochemical parameters before exercise, two weeks after exercise, and post-exercise. During the experiment, the WBC pattern was different between the control group and the exercise group. In the control group, there was no change from the initiation of the experiment until the end of four weeks. However, in the exercise group, the WBC count was significantly decreased at two weeks of exercise compared to pre-exercise and increased at the end of exercise $(p<0.05)$. Regarding aspartate aminotransferase (AST) and ALP serum levels, there was no change in the control group during the experiment, but in the exercise group, the post-exercise values showed a significant change compared to levels before exercise and at two weeks of exercise $(p<0.05)$. In the exercise group, glucose was significantly decreased at two weeks of exercise compared to pre-exercise and post-exercise $(p<0.05)$, but there was no change in the control group. There was no difference in effect for other hematological and serum biochemical parameters (Table S1).

Table 4. Changes in canine hematological and biochemical responses during exercise.

\begin{tabular}{|c|c|c|c|c|}
\hline Parameters & Group & Pre-Exercise & $\begin{array}{l}2 \text { Weeks of } \\
\text { Exercise }\end{array}$ & Post-Exercise \\
\hline $\mathrm{WBC}(\mathrm{k} / \mu \mathrm{L})$ & $\begin{array}{l}\text { Control } \\
\text { Exercise }\end{array}$ & $\begin{array}{c}7810.0 \pm 1120.6 \\
8650.0 \pm 3085.7^{\mathrm{A}}\end{array}$ & $\begin{array}{c}7313.3 \pm 2043.4 \\
4916.6 \pm 1097.9^{\mathrm{B}}\end{array}$ & $\begin{array}{c}7543.3 \pm 976.5 \\
6806.6 \pm 450.8^{C}\end{array}$ \\
\hline AST (U/L) & $\begin{array}{l}\text { Control } \\
\text { Exercise }\end{array}$ & $\begin{array}{c}37.6 \pm 4.0 \\
35.0 \pm 2.6^{\mathrm{A}}\end{array}$ & $\begin{array}{c}30.0 \pm 1.0 \\
31.0 \pm 5.5^{\mathrm{A}}\end{array}$ & $\begin{array}{c}30.6 \pm 5.5 \\
26.3 \pm 2.0^{\mathrm{B}}\end{array}$ \\
\hline $\operatorname{ALP}(\mathrm{U} / \mathrm{L})$ & $\begin{array}{l}\text { Control } \\
\text { Exercise }\end{array}$ & $\begin{array}{c}35.3 \pm 8.6 \\
40.0 \pm 4.5^{\mathrm{A}}\end{array}$ & $\begin{array}{c}34.8 \pm 2.0 \\
44.0 \pm 2.6^{\mathrm{A}}\end{array}$ & $\begin{array}{c}30.3 \pm 5.1 \\
49.6 \pm 7.0^{\mathrm{B}}\end{array}$ \\
\hline $\begin{array}{l}\text { Glucose } \\
(\mathrm{mmol} / \mathrm{L})\end{array}$ & $\begin{array}{l}\text { Control } \\
\text { Exercise }\end{array}$ & $\begin{array}{c}110.6 \pm 7.0 \\
110.3 \pm 5.6^{\mathrm{A}}\end{array}$ & $\begin{array}{c}110.3 \pm 7.7 \\
101.3 \pm 7.5^{\mathrm{B}}\end{array}$ & $\begin{array}{c}104.6 \pm 6.6 \\
108.0 \pm 9.6^{\mathrm{A}}\end{array}$ \\
\hline
\end{tabular}

All data are represented as mean \pm SEM. ${ }^{A-C}$ superscripts denote statistically significant values between preexercise, two weeks of exercise, and post-exercise for the exercise group $(p<0.05)$. Results were derived from three dogs in the control group and 3 dogs in the exercise group. 


\subsection{Effect of Exercise on the Expression of Immune-Related Cytokine Genes}

Real-time PCR was performed to analyze the expression level of immune-related cytokine genes in the leukocytes of the treadmill endurance exercise group and the control group. As a result, the mRNA expression of pro-inflammatory cytokines TNF- $\alpha$, IFN- $\gamma$, and IL-1 $\beta$ were significantly decreased compared to the control group after exercise (Figure 2, $p<0.05)$. There was no significant difference in IL- 6 and IL- 8 between the two groups during exercise.
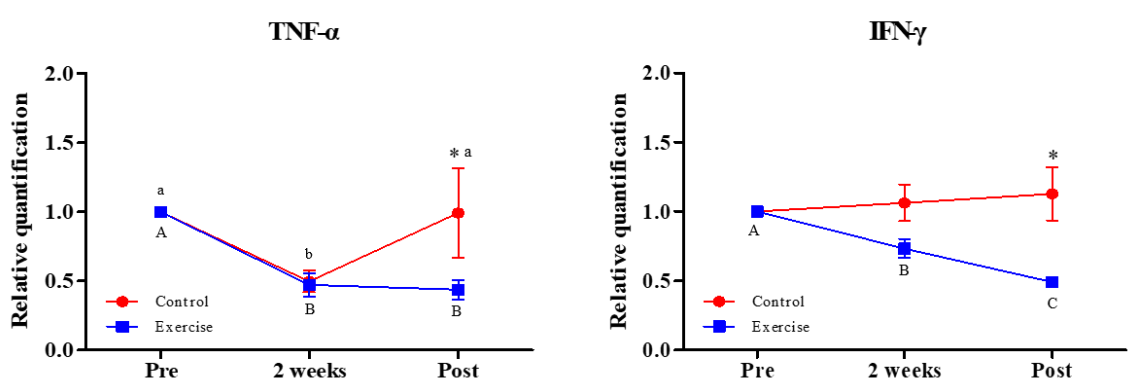

IL-1 $\beta$

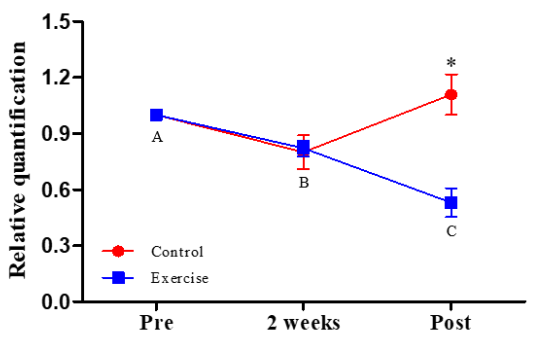

IL-6

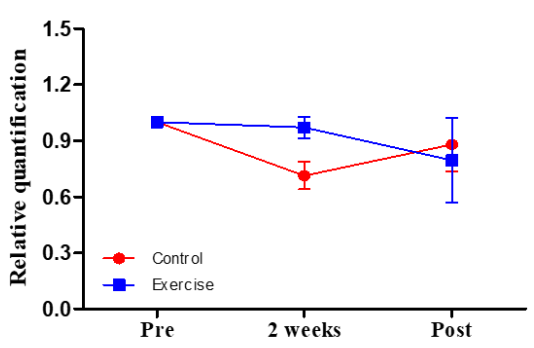

IL-8

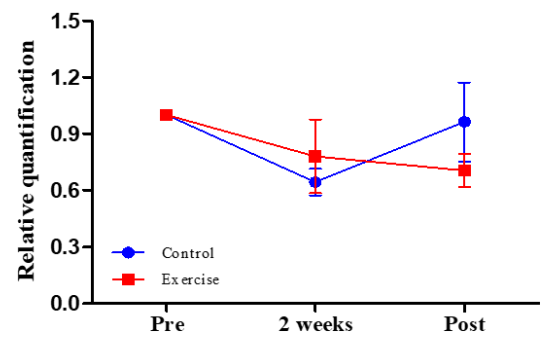

Figure 2. Comparison of changes in pro-inflammatory cytokines according to the duration of exercise. * Denotes a statistically significant comparison $(p<0.05)$ between groups at that time point. ${ }^{(a, b)}$ superscripts denote statistically significant comparisons between pre-exercise, two weeks of exercise, and post-exercise for the control group $(p<0.05)$. ${ }^{(\mathrm{A}-\mathrm{C})}$ superscripts denote statistically significant values between pre-exercise, two weeks of exercise, and post-exercise for the exercise group $(p<0.05)$.

IL-4 significantly decreased in the exercise group after exercise compared to the control group, and IL-10 was not different between groups (Figure $3, p<0.05$ ).

IL-4

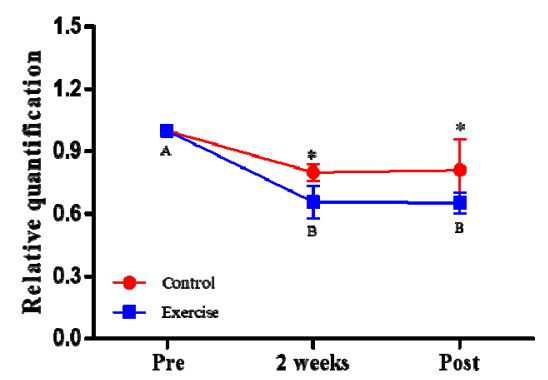

IL-10

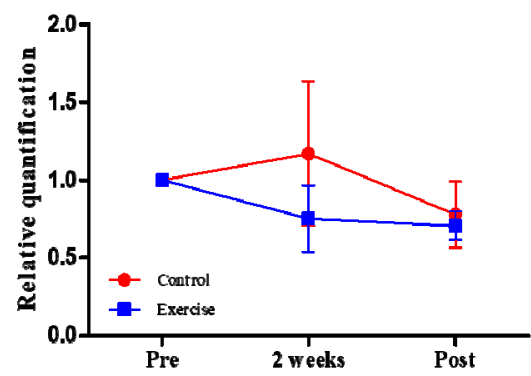

Figure 3. Comparison of changes in anti-inflammatory cytokines according to the duration of the exercise period. * Denotes statistically significant comparison $(p<0.05)$ between groups at that time point. ${ }^{(A, B)}$ superscripts denote statistically significant values between pre-exercise, two weeks of exercise, and post-exercise for the exercise group $(p<0.05)$.

\section{Discussion}

The purpose of this study was to investigate the effect of short-term endurance exercise on hematological variables and cytokine regulation in healthy dogs. We found positive 
changes in WBC, AST, ALP (Table 4), and glucose following moderate-intensity endurance exercise and significant changes in pro-inflammatory cytokines, including TNF- $\alpha$, IFN- $\gamma$, and IL-1 $\beta$, and anti-inflammatory cytokine IL-4 (Figures 2 and 3). To the best of our knowledge, this is the first study to confirm the proper regulation of cytokines through exercise in healthy dogs, suggesting that WBC may be involved in the primary mechanism by which exercise-induced cytokines are regulated. Adequate adaptation to the experimental environment and exercise program is required, as dogs may show resistance to standing on the treadmill and exercise or may be easily distracted by their sense of smell and hearing [28]. The current study provided the beagles sufficient time to adapt to the experiment and adequate compensation (walking, play, communion, etc.). No dogs experienced any side effects or maladaptive behavior following exercise, and there were no abnormal findings in the health checkup conducted by the veterinarian.

Hematological and serum biochemical analysis is an effective method that evaluates physiological changes and health abnormalities in dogs who have exercised [29-31]. Elevated WBC count is used as a risk indicator for cardiovascular disease, inflammation, and excessive physical and psychological stress [32-35]. In this study, dogs who exercised for a total of four weeks showed a significant decrease in WBC count at the second week of exercise but returned to pre-exercise levels after completing the exercise program. Exercise in the early stages of training causes mild oxidative stress and increases cell damage and inflammation [36,37], but continuous training effectively improves anti-inflammatory and antioxidant capacity $[36,38]$. Accordingly, these changes in WBC count are considered to appropriately represent the adaptation of exercise. Long-term and high-intensity exercise is known to induce a decrease in WBC count in humans [39], and our study found that moderate-intensity exercise for four weeks also reduces WBC count in dogs. Through this, the exercise program conducted in this study is considered to have sufficient intensity and duration to positively change canine WBC count.

Horn et al. [40] reported a significant positive correlation between endurance exercise and WBC reduction. Neutrophils contribute phagocytosis to the inflammatory response, which, for exercise, occurs following repeated eccentric contractions that cause local muscle damage and release of chemokines and cytokines [41,42]. Neutrophils are produced in the bone marrow from the myeloid cell line [43] and are the major subset of the polymorphonuclear phagocytes, representing $50-75 \%$ of total circulating leukocytes [44]. Furthermore, neutrophils play a central role in infection, genetic disorders, inflammation, and innate immune function $[45,46]$. Neutrophils are also the most abundant effector cells in the immune system and are the cells that first migrate from the bloodstream to the site of tissue inflammation in response to pathogens or inflammation [47]. Caused by stress from exercise, when inflammation produced by tissue and immune cells accumulates, it circulates through the blood to the bone marrow to activate hematopoietic stem cells and release numerous cytokines, such as TNF- $\alpha$, IFN- $\gamma$, and IL-6, which are responsible for the spread and regulation of inflammation [43,48-51]. Neutrophils are mobilized through the process of emergency granulocyte formation for the proper regulation of cytokines [52]. Since neutrophils are cells with a short lifespan of 6-8 h [53], a large number of neutrophils are required to be produced [52]. Various prior studies have shown that human and animal models show a decrease in WBCs and neutrophils after endurance exercise $[40,45,54,55]$. Therefore, the transient decrease in WBCs identified in this study is believed to be the result of these mechanisms.

Recently, opinions have been raised that WBCs could be a source of cytokines [56-58]. Changes in TNF- $\alpha$, IFN- $\gamma$, IL- $1 \beta$, and IL- 4 were identified in dogs that exercised in this study. Cytokines are divided into T helper 1 (Th1) and Th2 T lymphocytes according to the profile produced [59]. TNF and IFN included in Th1 are activated in intracellular inflammatory responses, whereas IL-4, classified as Th2, is activated in extracellular inflammatory responses [59,60]. In general, exercise is known to induce an increase in IL-6 [61,62]. The changes in IL-6 identified in this study are unexpected results, and the reason for this is difficult to know. However, even in a study investigating changes in aerobic exercise (running 
and cycling), the changes in IL-6 according to the type of exercise did not coincide with each other [63], and it was reported that the health status of the subjects and the increase in IL-6 were inversely proportional [64-66]. Considering this, it may have been difficult to confirm a significant increase in IL-6 because healthy dogs participated in this study.

Although moderate levels of exercise are known to have a positive effect on the immune system, including reduced upper respiratory tract infections and inflammation $[67,68]$, strenuous exercise is known to increase pro-inflammatory cytokines, such as TNF- $\alpha$, IL-1 $\beta$, and IL-6, by reducing immune cell function and natural killer cell response [69-71]. Traditionally, IL-6 is the fastest-expressed inflammatory cytokine in the circulatory system in stressful situations and is known to promote the production of TNF- $\alpha$ and IL-1 $\beta$ [72,73]. On the other hand, in an IL-6 knockout mouse model, TNF- $\alpha$ was slightly decreased after exercise, and it was shown that the expression of TNF- $\alpha$ can be inhibited by other pathways as well as through independent pathways by IL-6 [74]. As a result of moderate exercise in healthy young adults for six weeks, similar to the exercise period of this study, TNF- $\alpha$ was significantly reduced compared to the high-intensity exercise group [75]. In another study, healthy adults performed moderate-intensity endurance exercises for four weeks, and TNF- $\alpha$ was significantly reduced post-exercise [22]. Given this, dogs exhibiting reduced TNF- $\alpha$ due to proper levels of exercise intensity fits well with the existing literature. Meanwhile, many $\mathrm{CD} 8^{+} \mathrm{T}$ cells are $\beta 2$-adrenergic, producing IFN- $\gamma$ and IL-1 $\beta[76,77]$. In dogs, as in humans, exercise is generally known to activate epinephrine [78,79], and increased epinephrine appears to inhibit $\mathrm{T}$ cell receptors, reducing CD8 ${ }^{+} \mathrm{T}$ cells $[80,81]$ and leading to a decrease in IFN and IL- $1 \beta$. The same results were found in humans and horses who performed aerobic exercise [76,82].

IL-4, a potent anti-inflammatory cytokine, inhibits pro-inflammatory cytokines [83], and the current study confirmed a decrease in IL-4 along with a decrease in pro-inflammatory cytokine levels in dogs post-exercise. Previous studies have reported contrasting results regarding IFN- $\gamma$ and IL-4 and exercise $[84,85]$, but the results of this study were different from those of the preceding studies. Therefore, this is not surprising, as cytokine responses to exercise are sometimes conflicting or controversial $[76,86,87]$ and can lead to different outcomes depending on study design [82]. The development of the canine immune system shares many similarities to the human as many of the parameters (i.e., common gamma chain, receptors for interleukins, and cytokines) that describe the dog's immune system are more similar to humans than rodents [88]. Thus, dogs have played an important role in immune system research as a pre-clinical model for human drug development, including the study of primary immunodeficiency disease. Cytokines involved in lymphocyte development and function are also reported to be almost identical in dogs and humans [88]. In the present study, changes in cytokines to exercise in dogs will serve as reference data for predicting changes in humans and contribute as an animal model to prove immune effects during exercise.

\section{Conclusions}

The current study demonstrated that short-term moderate-intensity endurance exercise significantly affects WBC count and mRNA cytokine expression in canine blood and may have a meaningful effect on immune health in dogs. In order to improve the health of dogs, the intensity of exercise above the medium intensity applied here and continuous participation in exercise for more than four weeks and three times a week is considered necessary.

This study has several limitations. Due to the characteristics of dogs, which are medium-heavy animals, it was difficult to secure sufficient populations, so the number of samples in this study was small. Since our research has been conducted only on healthy male beagles, we need a research design that considers gender, breed, and disease. Through this, further studies are needed to examine whether exercise interventions can effectively control cytokines by applying moderate-intensity short-term endurance exercise to a variety of dog breeds. 
Supplementary Materials: The following supporting information can be downloaded at: https: / / www.mdpi.com/article/10.3390/app12010215/s1, Table S1. Analysis of hematological parameters and serum biochemistry in dogs.

Author Contributions: J.-H.K., H.S.L. conceptualized and designed the research; J.-H.K., H.S.L., H.J.O. and K.R. performed experiments; J.-H.K., H.S.L., H.J.O. and K.R. analyzed data; J.-H.K., H.S.L., H.J.O. and K.R. interpreted experimental results; J.-H.K., H.S.L. and H.J.O. wrote the first draft of the manuscript; J.-H.K. and H.S.L. edited and revised the manuscript. The results of the present study are presented ethically, without plagiarism, tampering, or manipulation by the researchers. All authors have read and agreed to the published version of the manuscript.

Funding: This study was performed with the support of the Cooperative Research Program for Agriculture Science and Technology Development (a supportive managing project of the Center for Companion Animals Research, \#PJ014759022021) and the Rural Development Administration of the Republic of Korea.

Institutional Review Board Statement: "The Guide for the Care and Use of Laboratory Animals" published by the Institutional Animal Care and Use Committee (IACUC) of Hanyang University (Approval number: HYU-2020-0073A, Approval date: 11 May 2020) and Seoul National University (Approval number: SNU-180731-2, Approval date: 11 August 2018).

Informed Consent Statement: Not applicable.

Conflicts of Interest: The authors declare no conflict of interest.

Data Availability: All data used to support the findings of this study are included in the article. The analyzed data during the current study are available from the corresponding author upon reasonable request.

\section{References}

1. MacKinnon, M. 'Sick as a dog': Zooarchaeological evidence for pet dog health and welfare in the Roman world. World Archaeol. 2010, 42, 290-309. [CrossRef]

2. Franklin, A.J.H. "Be[a]ware of the Dog": A Post-Humanist Approach to Housing. Hous. Theory Soc. 2006, 23, 137-156. [CrossRef]

3. Overall, K.L. Clinical Behavioral Medicine for Small Animals; Mosby-Year Book, Inc.: Maryland Heights, MO, USA, 1997.

4. Westgarth, C.; Christley, R.M.; Marvin, G.; Perkins, E. I Walk My Dog Because It Makes Me Happy: A Qualitative Study to Understand Why Dogs Motivate Walking and Improved Health. Int. J. Environ. Res. Public Health 2017, 14, 936. [CrossRef] [PubMed]

5. Medicine, A.C.o.S. ACSM's Guidelines for Exercise Testing and Prescription; Lippincott Williams \& Wilkins: Philadelphia, PA, USA, 2013.

6. $\quad$ Radin, L.; Belic, M.; Bottegaro, N.B.; Hrastic, H.; Torti, M.; Vucetic, V.; Stanin, D.; Vrbanac, Z. Heart rate deflection point during incremental test in competitive agility border collies. Vet. Res. Commun. 2015, 39, 137-142. [CrossRef] [PubMed]

7. Rovira, S.; Munoz, A.; Riber, C.; Benito, M. Heart rate, electrocardiographic parameters and arrhythmias during agility exercises in trained dogs. Rev. Med. Vet. Toulouse 2010, 161, 307-313.

8. Lee, H.S.; Oh, H.J.; Lee, S.H.; Kim, J.W.; Kim, J.-H. Comparison of physiological and hematological responses to treadmill exercise in younger and older adult dogs. Korean J. Sport Sci. 2019, 30, 677-688. [CrossRef]

9. Piccione, G.; Casella, S.; Panzera, M.; Giannetto, C.; Fazio, F. Effect of Moderate Treadmill Exercise on Some Physiological Parameters in Untrained Beagle Dogs. Exp. Anim. Tokyo 2012, 61, 511-515. [CrossRef]

10. German, A.J.; Blackwell, E.; Evans, M.; Westgarth, C. Overweight dogs exercise less frequently and for shorter periods: Results of a large online survey of dog owners from the UK. J. Nutr. Sci. 2017, 6, e11. [CrossRef]

11. Ostrowski, K.; Schjerling, P.; Pedersen, B.K. Physical activity and plasma interleukin-6 in humans-Effect of intensity of exercise. Eur. J. Appl. Physiol. 2000, 83, 512-515. [CrossRef]

12. Duncan, G.E.; Anton, S.D.; Sydeman, S.; Newton, R.L.; Corsica, J.A.; Durning, P.E.; Ketterson, T.U.; Martin, A.D.; Limacher, M.C.; Perri, M.G. Prescribing exercise at varied levels of intensity and frequency-A randomized trial. Arch. Intern. Med. 2005, 165, 2362-2369. [CrossRef]

13. Pedersen, B.K.; Toft, A.D. Effects of exercise on lymphocytes and cytokines. Brit. J. Sport Med. 2000, 34, 246-251. [CrossRef]

14. Hasegawa, H.; Mizoguchi, I.; Chiba, Y.; Ohashi, M.; Xu, M.L.; Yoshimoto, T. Expanding Diversity in Molecular Structures and Functions of the IL-6/IL-12 Heterodimeric Cytokine Family. Front. Immunol. 2016, 7, 479. [CrossRef]

15. Hung, Y.-L.; Suzuki, K. The pattern recognition receptors and lipopolysaccharides (LPS)-induced systemic inflammation. Int. J. Res. Stud. Med. Health Sci. 2017, 2, 1-7.

16. Suzuki, K. Cytokine Response to Exercise and Its Modulation. Antioxidants 2018, 7, 17. [CrossRef] 
17. Nemzek, J.A.; Agrodnia, M.D.; Hauptman, J.G. Breed-specific pro-inflammatory cytokine production as a predisposing factor for susceptibility to sepsis in the dog. J. Vet. Emerg. Crit. Care 2007, 17, 368-372. [CrossRef]

18. Kingsnorth, A.J.G. Role of cytokines and their inhibitors in acute pancreatitis. Gut 1997, 40, 1. [CrossRef]

19. Chen, Y.W.; Li, Y.T.; Chen, Y.C.; Li, Z.Y.; Hung, C.H. Exercise Training Attenuates Neuropathic Pain and Cytokine Expression After Chronic Constriction Injury of Rat Sciatic Nerve. Anesth. Analg. 2012, 114, 1330-1337. [CrossRef] [PubMed]

20. De Gonzalo-Calvo, D.; Davalos, A.; Montero, A.; Garcia-Gonzalez, A.; Tyshkovska, I.; Gonzalez-Medina, A.; Soares, S.M.A.; Martinez-Camblor, P.; Casas-Agustench, P.; Rabadan, M.; et al. Circulating inflammatory miRNA signature in response to different doses of aerobic exercise. J. Appl. Physiol. 2015, 119, 124-134. [CrossRef] [PubMed]

21. Wadley, A.J.; Chen, Y.W.; Lip, G.Y.; Fisher, J.P.; Aldred, S. Low volume-high intensity interval exercise elicits antioxidant and anti-inflammatory effects in humans. J. Sports Sci. 2016, 34, 1-9. [CrossRef]

22. Koh, Y.; Park, K.S. Responses of inflammatory cytokines following moderate intensity walking exercise in overweight or obese individuals. J. Exerc. Rehabil. 2017, 13, 472-476. [CrossRef]

23. Nieman, D.C.; Henson, D.A.; Austin, M.D.; Brown, V.A. Immune response to a 30-minute walk. Med. Sci. Sport Exer. 2005, 37, 57-62. [CrossRef] [PubMed]

24. Karlsson, I.; Hagman, R.; Johannisson, A.; Wang, L.; Karlstam, E.; Wernersson, S. Cytokines as Immunological Markers for Systemic Inflammation in Dogs with Pyometra. Reprod. Domest. Anim. 2012, 47, 337-341. [CrossRef] [PubMed]

25. Piantedosi, D.; Di Loria, A.; Guccione, J.; De Rosa, A.; Fabbri, S.; Cortese, L.; Carta, S.; Ciaramella, P. Serum biochemistry profile, inflammatory cytokines, adipokines and cardiovascular findings in obese dogs. Vet. J. 2016, 216, 72-78. [CrossRef] [PubMed]

26. Livak, K.J.; Schmittgen, T.D. Analysis of relative gene expression data using real-time quantitative PCR and the $2-\Delta \Delta C T$ method. Methods 2001, 25, 402-408. [CrossRef] [PubMed]

27. Ra, K.; Oh, H.J.; Kim, G.A.; Kang, S.K.; Ra, J.C.; Lee, B.C. High Frequency of Intravenous Injection of Human Adipose Stem Cell Conditioned Medium Improved Embryo Development of Mice in Advanced Maternal Age through Antioxidant Effects. Animals 2020, 10, 978. [CrossRef]

28. Ferasin, L.; Marcora, S. A pilot study to assess the feasibility of a submaximal exercise test to measure individual response to cardiac medication in dogs with acquired heart failure. Vet. Res. Commun. 2007, 31, 725-737. [CrossRef]

29. Lee, H.S.; Lee, S.H.; Kim, J.W.; Lee, Y.S.; Lee, B.C.; Oh, H.J.; Kim, J.H. Development of Novel Continuous and Interval Exercise Programs by Applying the FITT-VP Principle in Dogs. Sci. World J. 2020, 2020, 3029591. [CrossRef]

30. Cerqueira, J.A.; Restan, W.A.Z.; Fonseca, M.G.; Catananti, L.A.; de Almeida, M.L.M.; Feringer, W.H.; Pereira, G.T.; Carciofi, A.C.; Ferraz, G.D. Intense exercise and endurance-training program influence serum kinetics of muscle and cardiac biomarkers in dogs. Res. Vet. Sci. 2018, 121, 31-39. [CrossRef]

31. Lee, H.S.; Kim, J.H.; Oh, H.J.; Kim, J.H.J.A. Effects of Interval Exercise Training on Serum Biochemistry and Bone Mineral Density in Dogs. Animals 2021, 11, 2528. [CrossRef]

32. Lee, C.D.; Folsom, A.R.; Nieto, F.J.; Chambless, L.E.; Shahar, E.; Wolfe, D.A. White blood cell count and incidence of coronary heart disease and ischemic stroke, and mortality from cardiovascular disease in African-American and white men and women: The Atherosclerosis Risk in Communities Study. Circulation 2001, 103, 1357-1358.

33. Lippi, G.; Bassi, A.; Guidi, G.; Zatti, M. Relation between regular aerobic physical exercise and inflammatory markers. Am. J. Cardiol. 2002, 90, 820. [CrossRef]

34. Mccarthy, D.A.; Dale, M.M. The Leukocytosis of Exercise-A Review and Model. Sports Med. 1988, 6, 333-363. [CrossRef]

35. Perna, F.M.; Schneiderman, N.; LaPerriere, A. Psychological stress, exercise and immunity. Int. J. Sports Med. 1997, 18, S78-S83. [CrossRef] [PubMed]

36. Hoffman-Goetz, L.; Pervaiz, N.; Packer, N.; Guan, J. Freewheel training decreases pro- and increases anti-inflammatory cytokine expression in mouse intestinal lymphocytes. Brain Behav. Immun. 2010, 24, 1105-1115. [CrossRef] [PubMed]

37. Lin, C.L.; Wang, J.S.; Fu, T.C.; Hsu, C.C.; Huang, Y.C. Hypoxic Exercise Training Elevates Erythrocyte Aggregation. Appl Sci. 2021, 11, 6038. [CrossRef]

38. Wierzba, T.H.; Olek, R.A.; Fedeli, D.; Falcioni, G. Lymphocyte DNA Damage in Rats Challenged with a Single Bout of Strenuous Exercise. J. Physiol. Pharmacol. 2006, 57, 115-131. [PubMed]

39. Brines, R.; Hoffman-Goetz, L.; Pedersen, B.K. Can you exercise to make your immune system fitter? Immunol. Today 1996, 17, 252-254. [CrossRef]

40. Horn, P.L.; Pyne, D.B.; Hopkins, W.G.; Barnes, C.J. Lower white blood cell counts in elite athletes training for highly aerobic sports. Eur. J. Appl. Physiol. 2010, 110, 925-932. [CrossRef] [PubMed]

41. Shek, P.N.; Shephard, R.J. Physical exercise as a human model of limited inflammatory response. Can. J. Physiol. Pharm. 1998, 76, 589-597. [CrossRef]

42. Suzuki, K.; Totsuka, M.; Nakaji, S.; Yamada, M.; Kudoh, S.; Liu, Q.; Sugawara, K.; Yamaya, K.; Sato, K. Endurance exercise causes interaction among stress hormones, cytokines, neutrophil dynamics, and muscle damage. J. Appl. Physiol. 1999, 87, 1360-1367. [CrossRef]

43. Schnelle, A.N.; Barger, A.M. Neutropenia in dogs and cats: Causes and consequences. Vet. Clin. N. Am. Small Anim. Pr. 2012, 42, 111-122. [CrossRef]

44. Barreda, D.R.; Hanington, P.C.; Belosevic, M. Regulation of myeloid development and function by colony stimulating factors. Dev. Comp. Immunol. 2004, 28, 509-554. [CrossRef] 
45. Parisotto, R.; Pyne, D.; Martin, D.; Gore, C.; Fallon, K.; Fricker, P.; Hahn, A. Neutropenia in elite male cyclists. Clin. J. Sport Med. 2003, 13, 303-305. [CrossRef]

46. Abramson, J.; Wheeler, J. The Neutrophil: The Natural Immune System; Oxford University Press: Oxford, UK, 1993.

47. Mayadas, T.N.; Cullere, X.; Lowell, C.A. The Multifaceted Functions of Neutrophils. Annu Rev. Pathol. Mech. 2014, 9, 181-218. [CrossRef]

48. Maeda, K.; Malykhin, A.; Teague-Weber, B.N.; Sun, X.H.; Farris, A.D.; Coggeshall, K.M. Interleukin-6 aborts lymphopoiesis and elevates production of myeloid cells in systemic lupus erythematosus-prone B6.Sle1.Yaa animals. Blood 2009, 113, $4534-4540$. [CrossRef]

49. Baldridge, M.T.; King, K.Y.; Boles, N.C.; Weksberg, D.C.; Goodell, M.A. Quiescent haematopoietic stem cells are activated by IFN-gamma in response to chronic infection. Nature 2010, 465, 793-799. [CrossRef] [PubMed]

50. Pronk, C.J.H.; Veiby, O.P.; Bryder, D.; Jacobsen, S.E.W. Tumor necrosis factor restricts hematopoietic stem cell activity in mice: Involvement of two distinct receptors. J. Exp. Med. 2011, 208, 1563-1570. [CrossRef] [PubMed]

51. Mossadegh-Keller, N.; Sarrazin, S.; Kandalla, P.K.; Espinosa, L.; Stanley, E.R.; Nutt, S.; Moore, J.; Sieweke, M.H. M-CSF instructs myeloid lineage fate in single haematopoietic stem cells. Nat. Cell Biol. 2013, 497, 239-243. [CrossRef] [PubMed]

52. Manz, M.G.; Boettcher, S. Emergency granulopoiesis. Nat. Rev. Immunol. 2014, 14, 302-314. [CrossRef]

53. Cowland, J.B.; Borregaard, N. Granulopoiesis and granules of human neutrophils. Immunol. Rev. 2016, 273, 11-28. [CrossRef] [PubMed]

54. Malinowski, K.; Shock, E.J.; Rochelle, P.; Kearns, C.F.; Guirnalda, P.D.; McKeever, K.H. Plasma beta-endorphin, cortisol and immune responses to acute exercise are altered by age and exercise training in horses. Equine Vet. J. Suppl 2006, 267-273. [CrossRef]

55. Watson, H.G.; Meiklejohn, D.J. Leucopenia in professional football players. Brit. J. Haematol. 2001, 112, 826-827. [CrossRef] [PubMed]

56. Peake, J.M.; Della Gatta, P.; Suzuki, K.; Nieman, D.C. Cytokine expression and secretion by skeletal muscle cells: Regulatory mechanisms and exercise effects. Exerc. Immunol. Rev. 2015, 21, 8-25.

57. Tamassia, N.; Bianchetto-Aguilera, F.; Arruda-Silva, F.; Gardiman, E.; Gasperini, S.; Calzetti, F.; Cassatella, M.A. Cytokine production by human neutrophils: Revisiting the "dark side of the moon". Eur. J. Clin. Investig. 2018, e12952. [CrossRef] [PubMed]

58. Suzuki, K. Chronic Inflammation as an Immunological Abnormality and Effectiveness of Exercise. Biomolecules 2019, 9, 223. [CrossRef] [PubMed]

59. Szabo, S.J.; Kim, S.T.; Costa, G.L.; Zhang, X.; Fathman, C.G.; Glimcher, L.H. A novel transcription factor, T-bet, directs Th1 lineage commitment. Cell 2000, 100, 655-669. [CrossRef]

60. Gruenbacher, G.; Gander, H.; Rahm, A.; Nussbaumer, W.; Romani, N.; Thurnher, M. CD56+ human blood dendritic cells effectively promote TH1-type $\gamma \delta$ T-cell responses. Blood J. Am. Soc. Hematol. 2009, 114, 4422-4431. [CrossRef] [PubMed]

61. Steensberg, A.; van Hall, G.; Osada, T.; Sacchetti, M.; Saltin, B.; Pedersen, B.K. Production of interleukin-6 in contracting human skeletal muscles can account for the exercise-induced increase in plasma interleukin-6. J. Physiol. 2000, 529, 237-242. [CrossRef]

62. Fischer, C.P.; Hiscock, N.J.; Penkowa, M.; Basu, S.; Vessby, B.; Kallner, A.; Sjoberg, L.B.; Pedersen, B.K. Supplementation with vitamins $C$ and E inhibits the release of interleukin-6 from contracting human skeletal muscle. J. Physiol. 2004, 558, 633-645. [CrossRef]

63. Pedersen, B.K.; Febbraio, M.A. Muscle as an endocrine organ: Focus on muscle-derived interleukin-6. Physiol Rev. 2008, 88, 1379-1406. [CrossRef]

64. Harris, T.B.; Ferrucci, L.; Tracy, R.P.; Corti, M.C.; Wacholder, S.; Ettinger, W.H.; Heimovitz, H.; Cohen, H.J.; Wallace, R. Associations of elevated interleukin-6 and C-reactive protein levels with mortality in the elderly. Am. J. Med. 1999, 106, 506-512. [CrossRef]

65. Bruunsgaard, H.; Ladelund, S.; Pedersen, A.N.; Schroll, M.; Jorgensen, T.; Pedersen, B.K. Predicting death from tumour necrosis factor-alpha and interleukin-6 in 80-year-old people. Clin. Exp. Immunol. 2003, 132, 24-31. [CrossRef]

66. Ferrucci, L.; Corsi, A.; Lauretani, F.; Bandinelli, S.; Bartali, B.; Taub, D.D.; Guralnik, J.M.; Longo, D.L. The origins of age-related proinflammatory state. Blood 2005, 105, 2294-2299. [CrossRef] [PubMed]

67. Johannsen, N.M.; Swift, D.L.; Johnson, W.D.; Dixit, V.D.; Earnest, C.P.; Blair, S.N.; Church, T.S. Effect of Different Doses of Aerobic Exercise on Total White Blood Cell (WBC) and WBC Subfraction Number in Postmenopausal Women: Results from DREW. PLoS ONE 2012, 7, e31319. [CrossRef]

68. Lancaster, G.I.; Halson, S.L.; Khan, Q.; Drysdale, P.; Wallace, F.; Jeukendrup, A.E.; Drayson, M.T.; Gleeson, M. Effects of acute exhaustive exercise and chronic exercise training on type 1 and type $2 \mathrm{~T}$ lymphocytes. Exerc. Immunol.Rev. 2004, 10, 91-106. [PubMed]

69. Ostrowski, K.; Rohde, T.; Asp, S.; Schjerling, P.; Pedersen, B.K. Pro-and anti-inflammatory cytokine balance in strenuous exercise in humans. J. Physiol. 1999, 515, 287-291. [CrossRef]

70. Sugama, K.; Suzuki, K.; Yoshitani, K.; Shiraishi, K.; Kometani, T. Urinary excretion of cytokines versus their plasma levels after endurance exercise. Exerc. Immunol. Rev. 2013, 19, 29-48.

71. Lu, J.; Zhang, H.L.; Yin, Z.Z.; Tu, Y.; Li, Z.G.; Zhao, B.X.; Guo, J.Y. Moxibustion Attenuates Inflammatory Response to Chronic Exhaustive Exercise in Rats. Int J. Sports Med. 2012, 33, 580-585. [CrossRef] [PubMed]

72. Petersen, A.M.W.; Pedersen, B.K. The anti-inflammatory effect of exercise. J. Appl. Physiol. 2005, 98, 1154-1162. [CrossRef] 
73. Gokhale, R.; Chandrashekara, S.; Vasanthakumar, K.C. Cytokine response to strenuous exercise in athletes and non-athletes-An adaptive response. Cytokine 2007, 40, 123-127. [CrossRef]

74. Keller, C.; Keller, P.; Giralt, M.; Hidalgo, J.; Pedersen, B.K. Exercise normalises overexpression of TNF-alpha in knockout mice. Biochem. Bioph. Res. Co. 2004, 321, 179-182. [CrossRef]

75. Paolucci, E.M.; Loukov, D.; Bowdish, D.M.E.; Heisz, J.J. Exercise reduces depression and inflammation but intensity matters. Biol. Psychol. 2018, 133, 79-84. [CrossRef] [PubMed]

76. Ibfelt, T.; Petersen, E.W.; Bruunsgaard, H.; Sandmand, M.; Pedersen, B.K. Exercise-induced change in type 1 cytokine-producing CD8(+) T cells is related to a decrease in memory T cells. J. Appl. Physiol. 2002, 93, 645-648. [CrossRef] [PubMed]

77. Tan, K.S.; Nackley, A.G.; Satterfield, K.; Maixner, W.; Diatchenko, L.; Flood, P.M. $\beta 2$ adrenergic receptor activation stimulates pro-inflammatory cytokine production in macrophages via PKA-and NF-кB-independent mechanisms. Cell Signal. 2007, 19, 251-260. [CrossRef] [PubMed]

78. Moates, J.M.; Lacy, D.B.; Goldstein, R.E.; Cherrington, A.D.; Wasserman, D.H. Metabolic Role of the Exercise-Induced Increment in Epinephrine in the Dog. Am. J. Physiol. 1988, 255, E428-E436. [CrossRef] [PubMed]

79. Steensberg, A.; Toft, A.D.; Bruunsgaard, H.; Sandmand, M.; Halkjaer-Kristensen, J.; Pedersen, B.K. Strenuous exercise decreases the percentage of type $1 \mathrm{~T}$ cells in the circulation. J. Appl. Physiol. 2001, 91, 1708-1712. [CrossRef]

80. Marshall, G.D.; Agarwal, S.K. Stress, immune regulation, and immunity: Applications for asthma. Allergy Asthma Proc. 2000, 21, 241-246. [CrossRef] [PubMed]

81. Spellberg, B.; Edwards, J.E. Type 1 type 2 immunity in infectious diseases. Clin. Infect. Dis. 2001, 32, 76-102. [CrossRef] [PubMed]

82. Witkowska-Pilaszewicz, O.; Baska, P.; Czopowicz, M.; Zmigrodzka, M.; Szarska, E.; Szczepaniak, J.; Nowak, Z.; Winnicka, A.; Cywinska, A. Anti-Inflammatory State in Arabian Horses Introduced to the Endurance Training. Animals 2019, 9, 616. [CrossRef]

83. Volpin, G.; Cohen, M.; Assaf, M.; Meir, T.; Katz, R.; Pollack, S. Cytokine Levels (IL-4, IL-6, IL-8 and TGF beta) as Potential Biomarkers of Systemic Inflammatory Response in Trauma Patients. Int. Orthop. 2014, 38, 1303-1309. [CrossRef]

84. Hart, P.H.; Vitti, G.F.; Burgess, D.R.; Whitty, G.A.; Piccoli, D.S.; Hamilton, J.A. Potential Antiinflammatory Effects of Interleukin4-Suppression of Human Monocyte Tumor Necrosis Factor-Alpha, Interleukin-1, and Prostaglandin-E2. Proc. Natl. Acad. Sci. USA 1989, 86, 3803-3807. [CrossRef] [PubMed]

85. Zamani, A.; Salehi, I.; Alahgholi-Hajibehzad, M.J. Moderate exercise enhances the production of interferon- $\gamma$ and interleukin-12 in peripheral blood mononuclear cells. Immune Netw. 2017, 17, 186-191. [CrossRef]

86. Pedersen, B.K.; Steensberg, A.; Fischer, C.; Keller, C.; Ostrowski, K.; Schjerling, P. Exercise and cytokines with particular focus on muscle-derived IL-6. Exerc. Immunol. Rev. 2001, 7, 18-31. [PubMed]

87. La Gerche, A.; Inder, W.J.; Roberts, T.J.; Brosnan, M.J.; Heidbuchel, H.; Prior, D.L. Relationship between Inflammatory Cytokines and Indices of Cardiac Dysfunction following Intense Endurance Exercise. PLoS ONE 2015, 10, e0130031. [CrossRef]

88. Felsburg, P.J. Overview of immune system development in the dog: Comparison with humans. Hum. Exp. Toxicol. 2002, 21, 487-492. [CrossRef] [PubMed] 